\title{
Những dấu mốc chính trong lịch sử của quá trình bình duyệt
}

\author{
Nguyễn Thị Linh
}

\section{Trường Đại học Ngoại thương}

SSHPA (03-03-2020; https://sc.sshpa.com/post/5633) - Để thực sự hiểu và đánh giá được sự tiến bộ của quá trình bình duyệt khoa học, điều đầu tiên cần làm là dành một chút thời gian để nhìn lại quá trình phát triển và thay đổi liên tục của bình duyệt trong xuất bản học thuật. Trong bài viết $A$ brief history of peer review blog trên F1000Research Blog, tác giả Yousuf Al-Mousawi đã quay ngược thời gian và tìm về những dấu mốc chính trong lịch sử của quá trình bình duyệt.

\section{Sự phát triển của quá trình bình duyệt}

Thuật ngữ 'bình duyệt' (peer review) chỉ xuất hiện lần đầu tiên trong khoảng năm 1969 hoặc 1971 (theo từ điển Merriam-Webster và The Oxford English). Ngoài ra, thuật ngữ 'trọng tài'(referee) cũng được giới thiệu vào năm 1817 bởi George Greenough - một nhà địa chất học, và biết thới thuật ngữ này khi còn là một sinh viên luật. Do đó, trong phần thảo luận sau đây, việc sử dụng một trong hai thuật ngữ trên không có nghĩa là chúng nhất thiết phải được công nhận theo nghĩa hiện tại mà nên xem xét chúng trong bối cảnh lịch sử được đề cập đến.

Theo các nhà sử học, khái niệm của quá trình bình duyệt, được xem như một phương pháp đánh giá tác phẩm viết thời Hy Lạp cổ đại (Thế kỷ thứ 5 trước Công nguyên) hoặc các học giả Trung Đông (khoảng năm 900 sau Công nguyên). Một ý kiến khác cho rằng, bản mô tả tài liệu đầu tiên về quy trình bình duyệt, có lẽ trong một cuốn sách có tên là Ethics of the Physician, viết bởi một tác giả người Syria.

Nhân vật phổ biến hơn với nhiều người khi xuất hiện trên bài báo "Bản ghi đầu tiên của một bài phê bình trước khi xuất bản" (The first record of an editorial pre-publication peer-review) được cho là Henry Oldenburg, người sáng lập và biên tập viên đầu tiên của tạp chí Philosophical Transactions của Viện Hàn Lâm Khoa học Hoàng Gia Anh Quốc. Tuy nhiên, Oldenburg ông đã sử dụng phán đoán cá nhân của riêng mình trong quá trình đánh giá bài với tư cách là một biên tập viên mà không sử dụng hệ thống trọng tài, đánh giá bên ngoài.

Trong các nhận định khác, ấn phẩm bình duyệt được xuất bản đầu tiên là "Medical Essays and Observations" do Viện Hàn Lâm Khoa học Hoàng Gia Hoàng gia Edinburgh xuất bản năm 1731. Theo đó, người viết tuân thủ quy trình bình duyệt sau đây: "Các ghi chép của người gửi sẽ được phân phối theo chủ đề và chuyển cho những thành viên thông thạo nhất trong những vấn đề này. Không có báo cáo về danh tính của họ với tác giả". Mặc dù vậy, các thành viên ở đây được cho là các thành viên của viện chứ cũng chưa phải là những nhà bình duyệt độc lập. 
Năm 1752, Viện Hàn Lâm Khoa học Hoàng Gia Anh Quốc bắt đầu thực hiện một quy trình tương tự như trên bằng cách thành lập một Ủy ban quản lý những bản ghi chép (Committee on Papers). Chức năng của ủy ban này là xem xét tóm tắt các bản thảo và bỏ phiếu kín mà không cân thảo luận về những gì sẽ xuất bản. Vào những năm 1760, Viện Khoa học Hoàng gia Pháp cũng đã chỉ định các ủy ban nhỏ của các báo cáo viên (rapporteurs) để đánh giá bản thảo từ người ngoài. Tuy nhiên, các báo cáo viên này đã sử dụng các báo cáo bằng văn bản thay vì bỏ phiếu - làm cho quá trình này gần giống với bình duyệt hiện đại hơn.

\section{Sự khởi đâu của bình duyệt hiện đại}

Các nhà sử học nghiên cứu về khoa học đa phần đều đồng ý rằng thực tiễn đánh giá các bản thảo trước khi xuất bản (cái mà ngày nay chúng ta công nhận là bình duyệt truyền thống; sau đó được gọi là trọng tài) xuất hiện chủ yếu trong các Hội học thuật vào đâu thế kỷ XIX. Ví dụ, từ năm 1832, Viện Hàn Lâm Khoa học Hoàng Gia Anh Quốc bắt đầu tìm kiếm các báo cáo trọng tài bằng văn bản độc lập để đảm bảo rằng các quyết định biên tập của Ủy ban quản lý những bản ghi chép được dựa trên các ý kiến chuyên môn. Quá trình này dựa trên một gợi ý ban đâu được đưa ra bởi William Whewell vào năm 1831 và đây là lý do tại sao một số nhà sử học khoa học coi ông là người phát minh ra bình duyệt. Bản thân Viện Hàn lâm Khoa học Anh cũng dường như coi năm 1832 là thời điểm bình xét bản thảo được phát minh.

Sau đó, việc bình xét nhanh chóng được các tổ chức, viện khoa học khác chấp nhận và trở thành một phần căn bản trong quá trình xuất bản. Nó cũng được thông qua bởi các tạp chí độc lập vào cuối thế kỷ XIX. Ví dụ, vào năm 1893, British Medical Journal đã áp dụng đánh giá các bản thảo được gửi đến bằng cách sử dụng các trọng tài bên ngoài, những người này được biên tập viên coi là các chuyên gia có kiến thức và được công nhận trong lĩnh vực của bản thảo.

Bất chấp những phát triển trên, điểm đáng chú ý là việc áp dụng đánh giá bình duyệt vào thực tiễn còn chậm và thiếu kiểm soát. Điều này có thể được minh họa bằng câu chuyện nổi tiếng của Albert Einstein và tạp chí The Physical Review năm 1936. Einstein đã rất ngạc nhiên và cảm thấy xúc phạm khi bản thảo của ông đã được gửi bình duyệt. Ông đã rút bản thảo và phản đối rằng ông không ủy quyền cho biên tập viên làm việc đó. Do đó các bài báo khác của Einstein đều xuất bản trên tạp chí The Physical Review mà không qua bình duyệt. Trước đó, ông cũng đã xuất bản trong một tạp chí Đức, nơi các biên tập viên đã đánh giá và tự chọn bản thảo.

Sau Chiến tranh thế giới thứ 2 thì quá trình bình duyệt hiện đại mới được thiết lập từ sự gia tăng dần dần và ổn định trong nghiên cứu khoa học, chuyên môn hóa các bài báo 
và cạnh tranh cho việc xuất hiện trên các tạp chí xảy ra. Sau đó, nó dần dần bắt đầu lan truyền rộng rãi, mặc dù không theo một trật tự cụ thể, vào khoảng giữa thế kỷ 20 . Các tạp chí như Science, The Journal of the American Medical Association (JAMA) đã bắt đầu sử dụng các nhà bình duyệt bên ngoài vào những năm 1950 và 1960. Đối với Nature, bình duyệt viên bên ngoài trở thành một yêu cầu cơ bản để xuất bản vào năm 1973. Năm 1976, tạp chí The Lancet cũng bắt đầu áp dụng bình duyệt. Đến giữa những năm 1990, bình duyệt đã trở nên phổ biến.

\section{Công nghệ và bình duyệt}

Sự phát triển của Internet đã khiến thông tin phổ biến nhanh hơn bao giờ hết. Quá trình bình duyệt cũng không ngoại lệ. Xuất bản trên internet bắt đầu từ những năm 1990 và kích hoạt một cuộc cách mạng bình duyệt.

Theo đó, có lẽ sự đổi mới lớn nhất tiếp theo trong lịch sử của bình duyệt là việc áp dụng bình duyệt mở. Sự "mở" ở đây được xem như là đặc điểm của bình duyệt như danh tính mở, báo cáo, bản thảo trước khi được bình duyệt và nhận xét cuối cùng. Một số nhà xuất bản như BioMed Central, Frontiers, Peer], F1000Research, là những đơn vị tiên phong áp dụng các khía cạnh khác nhau và sáng tạo của bình duyệt kể từ khi khái niệm mới này xuất hiện.

Giữa năm 2007, nhiều tạp chí học thuật như BMJ, BMC, EMBO Journal, the Frontiers series, Royal Society Open Science, and Nature Communications sử dụng các phiên bản bình duyệt mở bằng cách ghi rõ tên các nhà phê bình hoặc ghi chú bên cạnh các bài báo.

\section{Tương lai rộng mở}

Sự tập trung vào tính minh bạch trong bình duyệt đang là động lực và sẽ sớm trở thành một tiêu chuẩn trong tương lai. Những đổi mới còn phụ thuộc vào những gì công nghệ có sẵn, nhưng cuối cùng, một trở ngại lớn nhất mà chúng ta cần phải vượt qua là thói quen và suy nghĩ của chính mình. Vẫn còn rất nhiều sự phản kháng từ một tỷ lệ nhỏ cộng đồng nghiên cứu hướng tới sự minh bạch, và đương nhiên sẽ cần thời gian để thích nghi và thay đổi xung quanh một quy trình bình duyệt hoàn toàn minh bạch.

\section{*Tài liệu tham khảo:}

Al-Mousawi Y. (2020). A brief history of peer review. F1000Research Blog (January 31). URL: https://blog.f1000.com/2020/01/31/a-brief-history-of-peer-review/.

Vuong QH. (2017). Open data, open review and open dialogue in making social sciences plausible. Nature: Scientific Data Updates (December 12). URL:

https://go.nature.com/2QdnUrW. 